\title{
Trends in EU Tax Policy: EU's Renewed Commitment to Tax Good Governance in the EU and Beyond
}

\section{INTRODUCTION}

This editorial is centred around the EU's renewed focus on tax good governance in the EU and vis-à-vis third countries. The European Commission has undertaken promoting a more cooperative relationship with third countries for which significant development has occurred. ${ }^{1}$ The focus of this contribution is on the Communication from the Commission to the European Parliament and the Council on Tax Good Governance in the EU and beyond, promoted as part of the 15 July 2020 Tax Package of the European Commission. ${ }^{2}$ The contribution evaluates the positive role of the EU Platform for Tax Good Governance and the relevance of other global policy players on global tax good governance, such as the Global Forum on Tax Transparency.

\section{COVID-19 Challenges to Good Governance}

Good governance is a commonly used concept to define the best practices of conduct of governments and international organizations that are based on inclusive decisionmaking and the exercise of government authorities with respect to administrative, political, and economic considerations. The best interests of society are at the heart of the concept of good governance and involve actors across the board in the decision-making process: from governmental to non-governmental bodies, from citizens to businesses/taxpayers, and from international cooperation to national consensus building.

The COVID-19 crisis has exposed the deficiencies of the international governance framework, not in the least by indicating that multilateralism and geopolitical strategic decision making are key elements in contending the public health and economic impacts of the COVID-19 pandemic. Governments will continue to engage in order to remedy the devastating effects of the pandemic.
However, the success of the response will largely depend on the societal approval of such measures, the values underpinning the system of governance, and the economic possibilities. More so, the public policy response of developed countries appears to be out of proportion in comparison to developing countries and other parts of the world where resources to tackle the pandemic are scarce. Scientific breakthroughs in developing vaccines with revolutionary technology have somewhat eased the anxieties regarding our societies' common future. Despite this, the reality remains sobering as it cannot be helped but to think how much damage the pandemic has already caused by long-term historical standards.

It is against this background that the concept of good governance is gaining increasing importance in the policy orientations of governments and the challenges facing the EU and the rest of the world.

\section{The EU'S RENEWED COMMITMENT to TAX GOOD GOVERNANCE IN THE EU}

The July 2020 Tax Package proposed the new policy commitments of the von der Leyen Commission. As part of this package, a Communication on Tax Good Governance was promoted that sought to strengthen the EU's international position vis-à-vis third countries. It promoted the principles of tax transparency and fair tax competition via reforms of the Code of Conduct Group for Business Taxation and improvements of the EU process of listing of non-cooperative jurisdictions for tax purposes. As such, a key element of this process will be the ability of the EU to challenge general elements of Member States' corporate tax regimes that bear features of being harmful rather than the existing practice of scrutinizing preferential regimes. Moreover, the communication aligns the EU tax policy commitments with the 2030 Sustainable Development Agenda that seeks to help developing countries in building resilient and robust tax systems.

\section{Notes}

International Monetary Fund (IMF), The Role of the IMF in Governance Issues: Guidance Note (IMF 1997).

European Commission, Communication from the Commission to the European Parliament and the Council on Tax Good Governance in the EU and Beyond COM(2020) 313 final (15 July 2020). 
Building upon the 2009 Communication on Promoting Good Governance in Tax Matters, the goals of the 2020 package are indeed more ambitious: synchronizing EU's efforts with the policy needs of developing countries in multiple areas:

- By leveraging the EU's robust tax transparency legislative framework (DAC/CbCR/mandatory disclosure rules) with the Anti Tax Avoidance Directive 1 (ATAD1) and ATAD2 as key anti-avoidance legislation and a new directive for tax dispute resolution, the EU is currently leading by example in promoting tax good governance and eradicating tax abuse in the EU and beyond. It is against this background that the EU external taxation dimension is gaining credibility on the international stage and with foreign partners;

- To ensure full consistency between the so-called 'backlisting criteria' applied within the EU and in relation to third countries, the commission intends to integrate the economic substance requirements into the code of conduct. By doing so, these strict standards would be applied both to Member States (to which the code applies) and to third countries with zero-taxation to which this already applies. This is particularly relevant considering the international discussion on minimum taxation which is an incentive to integrate the minimum tax requirements into the EU standards in order to avoid harmful tax competition within the single market and for all taxpayers that derive profits in the EU;

- Lastly, the EU process of blacklisting does not apply to the least developed countries due to their inability to comply with these strict criteria and the lack of capacity to act in accordance with the requirements as established by the EU.

\section{ROLE OF THE EU PLATFORM For tAX GOOD GOVERNANCE}

The European Commission Platform for Tax Good Governance is a key player in the process of promoting good governance in tax matters within the EU and beyond. Its most recent draft work programme recognizes the need for EU engagement with other relevant international actors such as the Addis Tax Initiative and the UN Sustainable Development Goals. At the heart of this renewed commitment is the idea of tax good governance as a key concept in assisting developing countries to build sufficient capacity to administer their tax systems more robustly and to support their efforts of sustainable domestic revenue mobilization. ${ }^{3}$

Such progressive commitments denote a continuation of the platform's earlier work ${ }^{4}$ and policy to influence Member States' external tax policy decisions, primarily by recognizing that a balanced approach to negotiation of double tax conventions (DTCs) with developing countries will prove to be beneficial for the EU in the long run. $^{5}$ It is worth reiterating that commitments in assisting developing countries to reduce and eradicate poverty by using the full spectrum of EU policies is already being undertaken by Member States and enshrined in primary EU law:

Union policy in the field of development cooperation shall be conducted within the framework of the principles and objectives of the Union's external action. The Union's development cooperation policy and that of the Member States complement and reinforce each other. Union development cooperation policy shall have as its primary objective the reduction and, in the long term, the eradication of poverty. The Union shall take account of the objectives of development cooperation in the policies that it implements which are likely to affect developing countries. The Union and the Member States shall comply with the commitments and take account of the objectives they have approved in the context of the United Nations and other competent international organisations. ${ }^{6}$

Recognizing that negotiation of double taxation conventions is a prerogative for Member States, it transpires that consistency must be ensured between Member States' external tax policy and the development policy of the EU in order to uphold the commitments already undertaken by the EU. As a corollary, the communication recognizes that fairness in tax matters can also be promoted via so-called 'tax good governance clauses' in relevant international agreements with third countries whereby the commission delivers on a longstanding policy of the European Parliament on tax good governance as 'core instruments of EU external policy'.

Historically, double taxation conventions have accorded a more significant portion of taxation rights to so-called 'residence' jurisdictions and have restricted those that are

\section{Notes}

'The EU Commission firmly believes that the work in this area should be fully aligned with the United Nations Sustainable Development Goals, also taking into consideration the severe repercussions of the COVID-19 fallout on the progress of the United Nations goals themselves', European Commission, Platform for Tax Good Governance, Shaping Future Tax Policies Together: Draft Work Programme 2020-2024, DOC: Platform/39/2020/EN (Nov. 2020).

4 European Commission, Platform for Tax Good Governance, Follow-up of the Communication on the External Strategy: Toolbox Spill-over Effects of EU Tax Policies on Developing Countries, Doc: Platform/26/2017/EN (Jun. 2017).

5 European Commission, Communication from the Commission to the European Parliament and the Council on an External Strategy for Effective Taxation, COM(2016) 24 final (28 Jan. 2016).

Article 208 of the Treaty on the Functioning of the European Union.

European Parliament, Resolution of 26 March 2019 on Financial Crimes, Tax Evasion and Tax Avoidance (2018/2121(INI)). 
applicable to 'source' jurisdictions. That is now perceived by developing countries as a restriction of their ability to tax a 'fair share' of the profits created within their jurisdictions. A consequence of this perceived imbalance in the structure of double tax conventions is that developing countries have long been in a position of ceding taxation rights with respect to economic income created at the 'source' within their jurisdiction. As a tool that enables any imbalance between developed and developing countries inherent in their tax treaties to be addressed, the Global Tax Advisers Platform recently endorsed the Platform for Collaboration on Tax Draft Toolkit. ${ }^{8}$

\section{Global taX POLICY AND DEVELOPMENT - THE EU AND THE GLOBAL FORUM ON TAX TRANSPARENCY}

The global recovery from the COVID-19 public health and economic consequences will be possible only by reference to the lowest common denominator. In the long run, developing countries must be supported in their efforts to tackle the pandemic by focusing on domestic resource mobilization as matter of good tax governance and functioning tax administrations. However, a key element of this process is the ownership of the policies in developing countries. A fully inclusive and collaborative approach is the peer-review process of the Global Forum on Tax Transparency which is an inclusive group with members from all over the globe and mirrors the efforts of the OECD's Inclusive Framework for Base Erosion and Profit Shifting (BEPS).

The Global Forum on Tax Transparency is at the forefront of international efforts to address the deficiencies of the present framework of international cooperation among tax jurisdictions and to provide the necessary tools for tax administrations to be able to effectively access data that will allow them to assess tax on income created within their jurisdictions. The core of the problems faced by emerging economies and particularly developing countries lays precisely in the lack of available information (i.e. on beneficial ownership) on the income or capital that belongs within their jurisdictions. The absence of (exchanged) data of foreseeable relevance and the inability to collect tax and revenue that is legitimately perceived by the public to belong in those countries profoundly affects the perception of fairness in the system, resulting in decreased tax morale and minimal compliance with the law. The work of the Global Forum has therefore been instrumental in addressing these issues.

Considering the number of issues and the importance of the task to address tax transparency, the challenges for tax good governance in a global setting, in particular for the EU vis-à-vis third countries, are manifold: fairness; effectiveness and robustness of the framework; and the objectivity of the process.

In addition to any technical issues that the process may face, the perception that such a process is fair will reinforce the sense of duty of compliance of jurisdictions that will undoubtedly redouble the efforts to be part of a system they perceive as equitable. Ultimately, as the number of jurisdictions being listed increases, the issues of whether all members (new and old) are treated equally may arise. Adequate opportunity to partake in the process should be guaranteed to all countries on an equal basis.

As such, whereby an objective process will guarantee equal treatment of jurisdictions in accordance with one applicable methodology. In light of the different stages in which jurisdictions are presently at concerning the readiness to implement tax good governance standards, concerns might arise in regards to the objectivity of the process and in relation to whether the same 'yardstick' has been applied to all jurisdictions. Hence, a single methodology that has sufficient acceptance in all jurisdictions must be put in place to guarantee the objectivity of the process in the future.

Further effectiveness and robustness of the process needs to be maintained. The scrutiny must remain merit-based which could be potentially challenging in a diverse and politically coloured international environment. The emergence of a multitude of international bodies of relevance should be considered. To that end, it is suggested that cooperation mechanisms between the EU, third countries and non-governmental stakeholders (like CFE Tax Advisers Europe/the Global Tax Advisers Platform) consider the implementation of any technical expertise that could be made available to partner countries.

\section{Conclusion}

Contending the COVID-19 impact in a globalized environment requires rational use of all of the public policy instruments at disposal. Consequently, the EU's renewed commitment to tax good governance is both timely and appropriate in scope. The focus on equalizing the process between the EU and third countries can benefit both the Member States and third partner countries. Given this positive evolution, both the EU and the partner countries will reap double dividends: benefits of implementing tax governance will strengthen the robustness of their tax systems which is increasingly important in the postvirus recovery and will ensure fairness in taxation as well as greater tax transparency and broadly accepted standards

\section{Notes}

8 Global Tax Advisers Platform (GTAP), Statement of the Global Tax Advisers Platform on the Platform for Collaboration on Tax Draft Toolkit for Negotiation of Tax Treaties (24 Sept. 2020), https://taxadviserseurope.org/blog/portfolio-items/6313/?portfolioCats=124\%2C125\%2C127 (accessed 29 Dec. 2020). 
in an international setting. The trends and evolution of the EU's tax good governance framework is promising, provided that the policy challenges vis-à-vis third countries are considered and implemented. This will ultimately ensure fairness of the process, effectiveness, and robustness of the tax good governance framework and the objectivity of the process as a whole.

Piergiorgio Valente The current President of CFE Tax Advisers Europe Email:p.valente@gebnetwork.it. 